\title{
Paideusis
}

\section{The Road to Newman's Clarity}

\section{John Britt}

Volume 3, Number 2, 1990

URI: https://id.erudit.org/iderudit/1073399ar

DOI: https://doi.org/10.7202/1073399ar

See table of contents

Publisher(s)

Canadian Philosophy of Education Society

ISSN

0838-4517 (print)

1916-0348 (digital)

Explore this journal

Cite this article

Britt, J. (1990). The Road to Newman's Clarity. Paideusis, 3(2), 36-42.

https://doi.org/10.7202/1073399ar

This document is protected by copyright law. Use of the services of Erudit (including reproduction) is subject to its terms and conditions, which can be viewed online.

https://apropos.erudit.org/en/users/policy-on-use/
This article is disseminated and preserved by Érudit.

Érudit is a non-profit inter-university consortium of the Université de Montréal, Université Laval, and the Université du Québec à Montréal. Its mission is to promote and disseminate research.

https://www.erudit.org/en/ 


\section{The Road to Newman's Clarity}

John Britt

\section{University of Dayton}

Even after years of studying John Henry Newman, a reader faces a pair of conclusions which seem to be in contradiction: Newman appears to write with total clarity and yet even the most skilled reader may miss Newman's chief point. Usually when this occurs, the scholar arrives at another pair of conclusions: Newman is utterly simple and Newman is exquisitely complex. The latter is, according to his critics, due either to excessive subtlety or to the issue. These parallel conclusions could be multiplied endlessly from the vast secondary literature which grows, in part because of such seeming contradictions.

Thus, it is not surprising to find in Martin Svaglic's stunning introduction to The Idea of a University, a remarkable example of missing the point. Even though his introduction contains a wealth of insights, it slips at what should have been one of its highpoints, his treatment of the mean.

\section{Mislèading Section}

No section of the Vlth Discourse can more mislead educators who shape their thought by excerpts rather than by a careful analysis of the text, than the 9th, which itself depends upon a correct reading of the 6th. Actually, the 9th section follows a far different principle than does the 6th. In the former, the principle is the lesser of the two evils, while, in the latter, the principle is that of the mean. When the link between these two sections is missed, the reader is misled into thinking that Newman is favouring what he is merely tolerating, while overlooking the value of one of Newman's most exceptional critiques of the educational habits of his time; the demand that students be stuffed with far more than they could integrate. But worse still, the efforts of the students to do this exorbitant task left them with neither the time, energy, nor skill necessary to think critically upon real problems.

\section{An Impossible Forced Choice}

In order to make the evil of this form of teaching completely manifest, Newman forces himself to make the impossible choice between stuffing our students or of letting them merely interact with one another. Thus, he opens the 9th section as follows:

I protest to you, Gentleman, that if I had to choose between a so-called University, which dispensed with residence and tutorial superintendence, and gave its degrees to any person who passed an examination in a wide range of subjects, and a University which had no professors or examinations at all, but merely brought a number of young men together for three or four years, and then sent them away as the University of Oxford is said to have done some sixty years since. If I were asked which of these two methods was the better discipline of the intellect,... I have no hesitation in giving preference to that University which did nothing, over that which exacted of its members an acquaintance with every science under the sun. ${ }^{1}$

Readers miss the fact that Newman is following up the issue of finding a method of achieving discipline which he has already detailed in section 6 , where 
he compares the many, the excessive, the defective, the mean, and the genius. The latter has no place in a University since the institution is meant for the ordinary. It also has no place for the many. Indeed, this group is the example of what a University is to save us from: "the influences of chance and necessity, above anxiety, suspense, unsettlement, and superstition."2 As Plato highlighted in the Republic, the issue of education is always between the good and the necessary. Newman recognizes the danger that society would expect the University to succumb to its criterion of necessity. Thus, he conjoined this with the thought of the many as a deleterious influence.

\section{Svaglic's Misunderstanding}

Svaglic holds that Newman thought that the mean is between the lack of any power of generalizing, and that of 'viewness'. At least two more times we come upon "view" and "viewness" in The Idea: first in the preface where he apologizes for a possible misunderstanding readers might form in assuming that the philosophical habit he expects to be the end of a university education is merely what we would call a well-rounded education, or what today we would call a general education--" would teach youths nothing soundly or thoroughly, and would dismiss them with nothing better than brilliant general views about all things whatever." 3

In a word, it philosophizes; for I suppose Science and Philosophy, in their elementary idea, are nothing else but this habit of viewing, as it may be called, the objects which sense conveys to the mind, of throwing them into system, and uniting and stamping them with one form. ${ }^{4}$

Shortly after, in the third section of Discourse IV, we find another reason for Svaglic's problem:

This method is so natural to us, as I have said, as to be almost spontaneous; and we are impatient when we cannot exercise it, ... we often put up with insufficient or absurd views or interpretations of what we meet with, rather than have none at all .... We cannot do without a view, and we put up with an illusion, when we cannot get a truth. ${ }^{5}$

Unless we make a careful study of section 6 of Discourse VI, we will continue the misunderstanding Newman seeks to avoid in writing a preface but into which a great interpreter such as Svaglic nonetheless falls along with those who know Newman only through excerpts. Unfortunately, it is only by having the pretext of An Essay in Aid of a Grammar of Assent, (which his earlier audiences could not have had since it was written some twenty-eight years later) can we really grasp his Aristotelian approach to the mean.

In a later work, Newman argues beyond the mean, but he knows what the mean is and expects that his readers would, too. Svaglic seems to have forgotten. Let us begin with this quotation:

Not only the assumptions and the goal but even the mode of reasoning are thoroughly Aristotelian: e.g., the distinction between liberal and useful knowledge; the definition of true knowledge in terms of its matter (facts, mere leaming) and its form (order, the investing of fact with an idea); and the portrayal, recalling the definition of virtue in the Nicomachean Ethics, of the truly educated person as a mean between the man of mere information who generalizes nothing and the man whose 'viewness' renders him impatient of fact and therefore unreliable in his assertions. ${ }^{6}$ 


\section{Newman's Assumption}

Let us begin with the reason why Newman assumes that he would not be misunderstood in his use of the terms "view," "viewing," and "viewness." The fact that he could justly assume this is clear from the example of Karl Jaspers who does not misunderstand the point. Jaspers raises the issue which Newman assumes would be grasped spontaneously by all: knowledge must always be a whole. ${ }^{8}$ This principle appears so important to Jaspers that he claims that bringing technology into the university constitutes a grave danger for bringing anything into the university which is not a whole would destroy, not only the university, but society itself. But as yet, we do not know whether technology is a whole. (Probably Jaspers gained substantiation for this insight from Newman's graphic description of the exorbitance--being out of orbit-resulting from the omission of theology from the curriculum). But just as he has taken the name of Newman's famous work for his own major work on education, Jaspers likewise has taken Newman's insight into the Platonic tradition as his own. At the heart of Discourse VI, "Knowledge Viewed in Relation to Learning," Newman claims:

... that it only is true enlargement of mind which is the power of viewing many things at once as one whole, of referring them severally to their true place in the universal system, of understanding their respective values, and determining their mutual dependence as his own. ${ }^{9}$ (emphasis added)

\section{How to Attain Enlargement}

After ascertaining that possessing this illumination and true philosophy is "the highest state to which nature can aspire, in the way of intellect," 10 Newman's problem is to determine how a person. can come to believe this statement. Here we have an interesting use made of the work of Plato and Aristotle in providing the options open to university faculty and students in facing this problem. We will consider the pretext as well as the context before analyzing the text in Discourse VI.

In The Statesman, Plato showed the difficulty in distinguishing the true from the false politician. ${ }^{11}$ In a famous digression on excess and defect, Plato provides Aristotle and Newman with the basis for their work on the mean and the illative sense. Plato noted that every form of art requires a search for evil as something to be avoided; and evil existed in the form of excess or defect. In other words, evil does not have an existence in itself for its existence is only in relation to the good. Aristotle advanced this consideration from the domain of art to ethics. In the pursuit of moral virtue, the agent was to admit to the extreme of defect or excess and develop the opposite tendency in order to achieve the mean. ${ }^{12}$ Newman carried Aristotle's advance further in his An Essay in Aid of a Grammar of Assent where he noted: "This power of judging and concluding, when in its perfection, I call the Illative Sense, and I shall best illustrate it by reference to parallel faculties, which we commonly recognize without difficulty."13 Aristotle described and explained this faculty of phronesis in the Nicomachean Ethics as judgment in relation to moral duty.

Newman not only showed its use in the illative sense but, earlier in The Idea of a University, he explicated its role in the university and its teaching. 
Newman reminds us that many educators and leaders of his society have been slow not only in admitting that the purpose of a university is to achieve wholeness of knowledge but also in recognizing that a qualitative state of mind is better than mere quantity of learning. Thus, in order to persuade those who had the power and the resources to put his university into existence, Newman had to develop a number of approaches towards fostering that state of mind which he had elaborated most carefully in Discourse V--Knowledge Its Own End.

\section{Educated Audience}

Because those in his audience, as a whole, had a university education, Newman could remind them of examples of the abuse of knowledge and contrast these with the best and second best. After dismissing consideration of the "many" who would have no place in the university, Newman could lay out the comparison of the excess, defect, and mean. Only after this could he separate the genius who, for reasons which differ from those that apply to the "many," also had no place in the university.

\section{Text and Interpretation}

In the following, the text is put in the form of "sense lines" so that the conversational style of Newman will emerge, aurally as well as visually. His voice makes a complicated and comparative argument hold together so that the order of the parts leads one to another. Thus, he begins with the question of excess which seemingly was common among the faculty.

The text and its interpretation, are as follows:

\section{Excess}

Men, whose minds are possessed with some one object,

take exaggerated views of its importance, are feverish in the pursuit of it,

make it the measure of things which are utterly foreign to it and

are startled and respond if it happens to fail them.

They are ever in alarm or in transport.

Such are "only possessed by their knowledge, not possessed of it."

Here Newman, completely aware of his use of grammar, employs the passive voice and contrasts the ablative and the genitive in modifying the results of his identical verb. Because men are "possessed by," they are prone to see everything else in light of their limited object. Hence, they expect more of it than is reasonable. This outcome contrasts sharply with the philosophical manner of pursuing the whole which conducts itself calmly, equably, and serenely, rather than feverishly. Such men put too much of themselves into their pursuit. Hence, they are open to despair when that into which they have put everything fails. Certainty makes such men assume that success is assured so that, when they fail, it appears unaccountable. On the other hand, in assuming any success is due to their insights and methods, they are beside themselves with joy when they succeed, but also vulnerable to collapse when their expected success ends in failure.

\section{Defect}

Those on the other hand who have no object or principle whatever to hold by, lose their way, every step they take.

They are thrown out, and do not know what to think or say, at every fresh juncture; 
they have no view of persons, or occurrences, or facts, which come suddenly upon them,

and they hang upon the opinions of others, for want of internal resources.

While the excessive have such a narrow focus, the defective lack both an objective and a starting point. Where the excessive are passive because of the overpowering burden of their special knowledge, the defective are passive because they need others not only to get started but also for direction as to where to go. They are susceptible to misdirection and misunderstanding in their learning because they do not think for themselves. Rather than having a height from which to measure and observe, they come to each crossroad as to an enigma. They are constantly surprised by the people they meet, the events which occur, and the facts they are given. Instead of searching for the truth, they search for answers from those who supposedly know. For the defective, life is a game which consists of answers without questions. They are at the mercy of what others believe.

\section{Mean}

The measure beyond both the excessive and the defective is the force of reason,

such an intellect cannot be partial,

cannot be exclusive,

cannot be impetuous,

cannot be at a loss.

cannot but be

patient, collected, and majestically calm,

because it discerns the end of every beginning,

the origin in every end, the law in every interruption, the limit in each

delay because it ever knows where it stands, and how its path lies from one

point to another.

The qualities of such an intellect are, in turn, the results of this activity; impartiality--the opposite of the bigot's manner, inclusive--the opposite of the ambit of the narrowminded; prudently decisive--the opposite of the obsessivecompulsive and the juvenile; the directed--the opposite of the lost. Moreover, such an intellect shows the qualities that Aristotle admired. ${ }^{14}$ The grounds for this admiration was the element of control evident in such a person, especially because of his or her acceptance of reality for what it is. When it continues in its chosen direction, such an intellect knows where and how it is to go.

\section{Sources in Plato and Aristotle}

Although Newman does not use the terminology of Plato and Aristotle, he returns to their examples and uses their criteria for picking out someone as educated. In the Grammar, we learn that, when the power of judging is brought to perfection, it is the illative sense--the mean in judgment. How does this come about? Newman know of such a discipline because of his familiarity with The Statesman. There, Plato shows how to develop the powers of discrimination by means of an intricate process of definition and dialectic. Students and teachers must train. In this training, the process must be repeated, for, unless one goes over the material a number of times, one is not in a position to know and think while knowing. Only then does the mind become active which is essential for Newman. Through such training, the intellect gains its elasticity. Because the 
mean demands far more than even the exceptional student is willing and able to achieve, Newman describes a number of its characteristics, knowing that, even with this elaboration, he has merely begun to indicate what the illative sense is and does. In the Grammar, he devotes his chief chapter to a much more subtle and complete description. Interestingly enough, when the claim that only the well educated truly possess this sense is put forward, controversy arises. For while some hold that Newman is calling upon the educated to help others in judgment since it is lacking in the latter, others hold that all have the illative sense. This is similar to the misunderstanding about the formal sense in Jean Piaget. For he, too, recognized that not only is there no guarantee everyone will achieve it, but that for most, it is only in their area of lifework that they achieve it. The rarity of the illative sense which Newman accepted seems to be another instance in which the leaders of our society are unwilling to face the facts of life.

\section{Newman's Expectation}

Newman, then, expected that many in his well-educated audience, would know why he used the terms "view," "viewing," and "viewness" as he did. His analogy began with sense knowledge and our usual way of considering knowledge visually. While Newman had asked us to ascend to a high point in order to look over the entire terrain before beginning our detailed study, he also accepted the limitation of his analogy. ${ }^{15}$ A student could remain with sense knowledge and not be able to move towards the intellectual form of view and viewing. When called upon to make the transition, the undisciplined student, as well as the excessively narrowminded one, would fall back upon views which were short of the mark but which to them appeared as comparable to the true meaning of view. Because society requires those on the road to an education to have a ready response to more than they are prepared to handle, the defective and the excessive learner proffer the pseudo-view for the real thing. Unfortunately, Newman expects more of us than we can deliver. We should have the qualities exhibited by Natalie Bluestone who, in Women and the Ideal Society examines the latent and avoidable biases carried by interpreters of Plato and also displays the freedom which comes from striving to interpret texts on their own terms. In similar fashion, Newman requires us to go beyond the debilitating biases which his interpreters have so often caused.

\section{Summary}

Svaglic did well in understanding The Idea until he came to its chief point. However, with the Grammar and in the absence of a careful textual analysis of sections 6 and 9, as well as earlier sections, we, too, could easily be misled. Newman could foresee this and wams us of it in his preface. He assumes that his readers would understand that his principle is that of wholeness on the one hand and the activity of the learner on the other. He, thus, took it for granted that his audience would understand, if warned, that he did not expect them to use his position on an absurd educational situation as he recalled from Oxford's past, as his criterion of discipline, nor forget that he had distinguished the many, the excess, the defect, the mean, and the genius. Yet, many of his readers, because they would miss the background in Plato and Aristotle from which he wrote, would not live up to Newman's expectation. If they had, we would 
probably have gained much more from The Idea than we have. The way to this gain is to return to the text. Newman expected that an audience possessed of an illative sense would have been up to distinguishing "view" and "viewness." Yet even when we have the text before us as well as the advantage of Newman's later Grammar and a lifetime of scholarship in the study of his works, we, as does Svaglic, can miss Newman's clarity. Once more, Plato's analogy of the cave proves apt--the brightness blinds us; and Aristotle's compendium also proves to be accurate--that which is most intelligible in itself is least intelligible to us and that which is least intelligible in itself is most intelligible to us. Thus, the clarity of Newman is in him, not in us.

\section{Conclusion}

In conclusion, we find that Plato's The Statesman shows the correct path which Newman followed. Educators must distinguish the true from the false, the good from the evil, the good from the necessary, and view from viewness. Yet this is a most difficult set of distinctions to make. It is not surprising, then, that educators fail at the very point where they could make the most difference. No doubt Shakespeare is correct when he observed that "Lilies that fester smell far worse than weeds." We should appreciate Svaglic for his outstanding offering but return to the text to correct what he missed.

\section{Notes}

${ }^{1}$ John Henry Newman, The Idea of a University, ed. Martin Svaglic (Notre Dame: University of Notre Dame Press, 1982), 109-110.

${ }^{2}$ Ibid., 104.

${ }^{3}$ Ibid., xliv.

${ }^{4}$ Ibid.

${ }^{5}$ Ibid., 56.

${ }^{6}$ Ibid., $\mathrm{xx}-\mathrm{xxi}$.

7John Ford, "'Dancing on the Tight Rope': Newman's View of Theology," Proceedings of the Fortieth Annual Convention, The Catholic Theological Society of America, 1985, 142.

${ }^{8} \mathrm{Karl}$ Jaspers, The Idea of a University, ed. Karl Deutsch (Boston: Beacon Press, 1959), 39.

${ }^{9}$ Idea, 103.

${ }^{10}$ Ibid.,104

${ }^{11}$ Plato, The Statesman, $284 \mathrm{c}-\mathrm{d}$.

12John Henry Newman, An Essay in Aid of a Grammar of Assent (Notre Dame: University of Notre Dame Press, 1979), 277.

${ }^{13}$ Ibid.

${ }^{14}$ Idea, 104.

${ }^{15}$ Ibid., 105. 